\title{
PHYSICAL PART IN MULTIDISCIPLINARY APPROACH IN REHABILITATION OF CARDIAC PATIENTS
}

\author{
${ }^{1}$ Associate Professor Roksolana Nesterak, \\ ${ }^{2}$ Associate Professor Myroslava Gasyuk \\ ${ }^{1}$ Ukraine, Ivano-Frankivsk, Ivano-Frankivsk National Medical University \\ Department of Internal Medicine No. 2 and Nursing; \\ ${ }^{2}$ Ukraine, Ivano-Frankivsk, State Pedagogical University "Vasyl Stefanyk Precarpathian National \\ University", Department of General and Clinical Psychology
}

DOI: https://doi.org/10.31435/rsglobal_wos/31082019/6652

\section{ARTICLE INFO}

Received: 27 June 2019

Accepted: 19 August 2019

Published: 31 August 2019

\section{KEYWORDS}

acute coronary syndrome, physical rehabilitation, program,

internal health image.

\begin{abstract}
The study was ained to analysis of the physical component in the complex rehabilitation of cardiac patients with acute coronary syndrome. Rehabilitation of patients with acute coronary syndrome was performed according to the author's "Program of Clinical and Psychological Rehabilitation of Cardiac Patients by Optimizing the Internal Health Image". The physical component in complex multidisciplinary rehabilitation of cardiac patients with acute coronary syndrome is necessary and provides the optimum possible recovery of the body, promotes adherence to treatment, provides awareness of the role of various disease development factors. In the course of physical rehabilitation, the patient chooses new strategies for recovery and preservation of health.
\end{abstract}

Citation: Roksolana Nesterak, Myroslava Gasyuk. (2019) Physical Part in Multidisciplinary Approach in Rehabilitation of Cardiac Patients. International Academy Journal Web of Scholar. 8(38), Vol.1. doi: 10.31435/rsglobal_wos/31082019/6652

Copyright: (C) 2019 Roksolana Nesterak, Myroslava Gasyuk. This is an open-access article distributed under the terms of the Creative Commons Attribution License (CC BY). The use, distribution or reproduction in other forums is permitted, provided the original author(s) or licensor are credited and that the original publication in this journal is cited, in accordance with accepted academic practice. No use, distribution or reproduction is permitted which does not comply with these terms.

Introduction. Rehabilitation of patients with coronary heart disease (CHD) is one of the imperative health problems worldwide. Modern cardiorehabilitation commits itself to improving the quality of life of such patients, which has led to an active scientific search for ways to improve its quality and effectiveness.

Various methods, such as reperfusion therapy, percutaneous coronary intervention (PCI), coronary artery bypass grafting (CABG), are widely used for the diagnosis and treatment of coronary heart disease. Improving their safety and clinical effectiveness has expanded the scope of indications for their use. Despite the fact that medical treatment and cardiovascular surgery become more effective, the quality of life of such patients increases slightly, the problem of recovery and their return to a full social life remains unresolved [1], [2].

According to the definition of the American Association of Cardiovascular Prevention and Rehabilitation, cardiorehabilitation is a coordinated multifaceted intervention aimed at optimizing the physical, psychological and social functioning of patients with cardiovascular disease, stabilization, slowing and even reversible development of atherosclerotic process, and as a result, decrease of morbidity and mortality [3].

The tasks of specialists are aimed at overcoming the limitations of the cardiovascular system caused by the sedentary lifestyle, as well as increasing mobility and independence, achieving psychological well-being, social and professional reintegration, and also the correction of the risk factors for 
cardiovascular diseases. The author's complex "Program of clinical-psychological rehabilitation of cardiac patients by optimization of the internal picture of health" ("the Program") is built on the basis of multimodal biopsychosocial, multidisciplinary and patient-centered approaches. "Program" rehabilitation is done through optimization of the internal picture of health (IPH) in general and of its components in particular (sensitive, emotional, cognitive, value-motivational, and behavioral) [4].

The team of specialists accompanying the patient at all stages of rehabilitation consists of a cardiologist, a physician of a physical and rehabilitation therapy, a psychologist, a physical therapist, an ergotherapist.

Particularly noteworthy is the physical component of complex radiorehabilitation. Thus, it is proved that physical training of patients with coronary heart disease effectively reduce the likelihood of recurrent heart attack and the risk of mortality [5,6]. Controlled physical activity is a key factor in improving the efficiency of rehabilitation in general and the quality of life in particular $[7,8]$. We have convincingly demonstrated that the internal picture of health can be a criteria for evaluating the overall rehabilitation progress of the patient [9], [10]. An important issue is to find out the contribution of the individual components of rehabilitation to the controlled parameters of IPH. In our work we try to isolate the peculiarities of the influence of the physical component of rehabilitation.

Purpose or the study: analysis of the physical component in the complex rehabilitation of cardiac patients with acute coronary syndrome (ACS).

Material and methods. We examined 135 patients with non-ST-segment elevation myocardial infarction (NSTEMI). The subjects are distributed according to treatment tactics (conservative or invasive). The clinical anamnestic characteristics of the sample is represented in Table. 1.

Table 1. Clinical-anamnestic characteristics of patients with NSTEMI

\begin{tabular}{|c|c|c|}
\hline \multirow{2}{*}{} & \multicolumn{2}{|c|}{ NSTEMI $(\mathrm{n}=135)$} \\
\cline { 2 - 3 } & Conservative Treatment $(\mathrm{n}=60)$ & $\begin{array}{c}\text { PCI } \\
(\mathrm{n}=75)\end{array}$ \\
\hline Avarage age & $68,38 \pm 1,30$ & $64,70 \pm 1,65$ \\
\hline Without AH & $9(15,00 \%)$ & $5(6,67 \%)$ \\
\hline AH I degree & - & $3(4,00 \%)$ \\
\hline AH II degree & $38(63,33 \%)$ & $48(64,00 \%)$ \\
\hline AH III degree & $13(21,67 \%)$ & $19(25,30 \%)$ \\
\hline DM type II & $19(31,67 \%)$ & $12(16,00 \%)$ \\
\hline CHF I & $51(85,00 \%)$ & $54(72,00 \%)$ \\
\hline CHF IIA & $8(13,33 \%)$ & $14(18,67 \%)$ \\
\hline HF (Killip) & - & $2(2,67 \%)$ \\
\hline I & - & $2(2,67 \%)$ \\
\hline II & - & $3(4,00 \%)$ \\
\hline III & - & - \\
\hline IV & & . \\
\hline TI
\end{tabular}

The age and sex sampling variation is consistent with the population (Table 2). Initial diagnosis of the patient was performed by a continuous method in the rehabilitation department after being in the Department of anesthesiology and resuscitation with the wards of intensive care, where the diagnosis and treatment tactics (conservative or invasive) were determined.

Table 2. Distribution of patients with NSTEMI by age and sex

\begin{tabular}{|l|c|c|}
\hline \multirow{2}{*}{ Age } & \multicolumn{2}{|c|}{ NSTEMI $(\mathrm{n}=135)$} \\
\cline { 2 - 3 } & $\begin{array}{c}\text { Conservative Treatment } \\
(\mathrm{n}=60)\end{array}$ & $\begin{array}{c}\text { PCI } \\
(\mathrm{n}=75)\end{array}$ \\
\hline Less than 45years & - & $2(2,7 \%)$ \\
\hline 45-59 years & $15(25,0 \%)$ & $26(34,7 \%)$ \\
\hline 60-74 years & $28(46,7 \%)$ & $31(41,3 \%)$ \\
\hline 75 and more years & $17(28,3 \%)$ & $16(21,3 \%)$ \\
\hline
\end{tabular}

Examination of patients was performed depending on the form of coronary heart disease and the method of revascularization. All patients received standard therapy for patients with coronary heart disease, depending on the form of coronary heart disease and in accordance with the recommendations of the Working Groups of the European and Ukrainian Societies of Cardiologists. 
Rehabilitation of patients with NSTEMI was performed according to the author's "Program of Clinical and Psychological Rehabilitation of Cardiac Patients by Optimizing the Internal Health Image" [4]. Diagnostic methods: Borg scale - the scale of individual perception of physical activity, 6minute test-walk, treadmill test, conversation, observation; adequate methods of statistical processing of the received information are applied. The complex of diagnostic methods is implemented at the key stages of rehabilitation: before the beginning of rehabilitation and 1 month after.

Objective contraindications were considered during the implementation of the physical component of multidisciplinary radiorehabilitation: unstable angina; uncontrolled supraventricular and ventricular arrhythmia; uncontrolled heart failure; high-speed blockade without artificial rhythm driver; pulmonary embolism and recently transmitted thrombophlebitis; causes not related to cardiac disease (orthopedic and other diseases).

Statistical processing was performed using the software system Statistica (version 10.0) with the calculation of the arithmetic mean, standard deviation, taking into account the methods for detecting differences for qualitative $(\chi 2)$ and quantitative $(t)$ variables. The difference was considered reliable at the result of $\mathrm{p}<0.05$ for each of the parameters.

Research results. The rehabilitation process is based on the basic principles of rehabilitation: complexity, validity, multidisciplinarity, individual approach, phasing, continuity, duration.

The tasks of the physical component of rehabilitation are: increase of functionality, reduction of anginal symptoms manifestations, increase of physical activity, modification of risk factors, improvement of life quality, improvement of social functioning, decrease of frequency of hospitalizations, decrease of recurrent cardiovascular events frequency, improving survival.

"Program" provides for taking into account the individual adaptive capacity of the patient, his age, anatomic-physiological, personal and energy features. The results of the rehabilitation process are determined by the rehabilitation potential (RP), by the definition of the RP - a complex of biological, psychophysiological and socio-psychological characteristics of the person, as well as factors of the social environment that allow to realize its potential opportunities for rehabilitation. On the basis of RP, a rehabilitation prognosis is constructed - a medically based probability of achieving the goals of rehabilitation with taking into account the features of the disease, individual resources and compensatory opportunities [11], [12].

The level of cooperation of patients with members of a multidisciplinary team has a significant impact on the effectiveness of rehabilitation, which depends directly on the individual characteristics of patients, in particular the age, cognitive characteristics, anxiety-depressive disorders in post heart attack patients, and on the attitude to their health, on recovery motivation etc. The state of the emotional-cognitive sphere should be taken into account for the correction of the individual rehabilitation program and the individual rehabilitation prognosis as a whole.

Regular physical activity and exercising form the program of the physical component of cardiorehabilitation. According to research, such activities have a positive effect on a various risk factors: increased fibrinolytic and decreased coagulant activity, anti-inflammatory effects, improved autonomic function, prevention and health recovery depending on age, decrease in endotheliumdependent vasodilation, which may also help to improve myocardial circulation in hyperemia. The benefit of physical training is to slow the progression of coronary heart disease [13].

The self-monitoring of patients of the physical component of rehabilitation was performed through a self-control diary with indicators of the Borg individual perception scale (Table 3). Selfcontrol combines subjective and objective metrics. These data are entered daily by patients during the dosed walk as a component of the physical rehabilitation of patients. Assessment of the perception of physical activity on the Borg scale is carried out also with other components of physical rehabilitation - morning gymnastics, therapeutic exercise, daily activities and also during diagnostic procedures - 6minute walk test, treadmill test. The use of evaluation scales simplifies communication in the team allows flexible response to changes in the patient's condition, allows for better quality of medical rehabilitation. Practical application of assessment scales allows to control the effectiveness of rehabilitation both to specialists and to the patient.

The results of rehabilitation by the "Program", namely its physical component, are presented in Tables 3 and 4. 
Table 3. Indicators of the test with 6-minute walk in patients with NSTEMI, who underwent conservative treatment after 1 month

\begin{tabular}{|c|c|c|c|c|}
\hline $\begin{array}{l}\text { Index, units of } \\
\text { measure }\end{array}$ & \multicolumn{2}{|c|}{$\begin{array}{l}\text { Traditional Treatment } \\
(\mathrm{n}=20)\end{array}$} & \multicolumn{2}{|c|}{$\begin{array}{l}\text { Traditional treatment and "Program" } \\
(\mathrm{n}=20)\end{array}$} \\
\hline & $\begin{array}{c}\text { Before } \\
\text { Exercises }\end{array}$ & $\begin{array}{c}\text { After } \\
\text { Exercises }\end{array}$ & Before Exercises & After Exercises \\
\hline $\mathrm{SBP}, \mathrm{mm} \mathrm{Hg}$ & $130,3 \pm 2,3$ & $\begin{array}{c}158,6 \pm 2,48 \\
\Delta+21,72\end{array}$ & $132,4 \pm 2,1$ & $\begin{array}{c}149,7 \pm 1,9 \\
\Delta+13,07\end{array}$ \\
\hline $\mathrm{DBP}, \mathrm{mm} \mathrm{Hg}$ & $77,3 \pm 2,3$ & $\begin{array}{l}86,4 \pm 1,9 \\
\Delta+11,77\end{array}$ & $74,4 \pm 1,8$ & $\begin{array}{c}80,2 \pm 1,8 \\
\Delta+7,80\end{array}$ \\
\hline Heart rate, min. & $75,4 \pm 2,9$ & $\begin{array}{l}87,2 \pm 2,6 \\
\Delta+15,65\end{array}$ & $74,0 \pm 2,1$ & $\begin{array}{c}79,3 \pm 1,3 * \\
\Delta+7,16\end{array}$ \\
\hline Feeling, score & $1,42 \pm 0,09$ & $\begin{array}{l}3,630,12 \\
\Delta+155,63\end{array}$ & $1,4 \pm 0,22$ & $\begin{array}{c}3,27 \pm 0,11^{*} \\
\Delta+133,57\end{array}$ \\
\hline Dyspnea, score & $1,9 \pm 0,11$ & $\begin{array}{c}2,38 \pm 0,09 \\
\Delta+25,26\end{array}$ & $1,87 \pm 0,06$ & $\begin{array}{c}2,06 \pm 0,08 \\
\Delta+10,16\end{array}$ \\
\hline $\begin{array}{l}\text { Angina pectoris, } \\
\text { score }\end{array}$ & $1,82 \pm 0,07$ & $\begin{array}{l}2,12 \pm 0,1 \\
\Delta+16,48\end{array}$ & $1,7 \pm 0,07$ & $\begin{array}{l}1,9 \pm 0,05 \\
\Delta+11,76\end{array}$ \\
\hline Traveled distance, $\mathrm{m}$ & \multicolumn{2}{|c|}{$362,2 \pm 13,2$} & \multicolumn{2}{|c|}{$\begin{array}{l}381,4 \pm 12,0 \\
\Delta+5,30\end{array}$} \\
\hline
\end{tabular}

Notes: 1. Significance of difference of indicators in comparison with values before intervention: $*<0,05$; $* *<0,01.2 . \Delta-$ the percentage of increase (+) / decrease (-) compared to the values before treatment.

The application of the developed rehabilitation program has contributed to the increase of exercise tolerance with the increase of the distance traveled. According to the 6-minute walk test an adequate increase in SBP and heart rate was noticed, with decreased anginal manifestations and increased load volume.

Analyzing subjective feelings of load tolerance on the Borg scale, we observed a lower mean score of shortness of breath and angina after exercising.

Such a positive dynamic was peculiar first of all to the patients, who after the PCI carried out rehabilitation measures under the proposed program (Table 4).

Table 4. 6-minute walk test scores with NSTEMI in patients undergoing invasive treatment after 1 month

\begin{tabular}{|c|c|c|c|c|}
\hline $\begin{array}{l}\text { Index, units of } \\
\text { measure }\end{array}$ & \multicolumn{2}{|c|}{$\begin{array}{l}\text { Traditional Treatmen } \\
(\mathrm{n}=25)\end{array}$} & \multicolumn{2}{|c|}{$\begin{array}{l}\text { Traditional treatment and "Program" } \\
\qquad(\mathrm{n}=25)\end{array}$} \\
\hline & $\begin{array}{c}\text { Before } \\
\text { Exercises }\end{array}$ & $\begin{array}{c}\text { After } \\
\text { Exercises } \\
\end{array}$ & Before Exercises & After Exercises \\
\hline $\mathrm{SBP}, \mathrm{mm} \mathrm{Hg}$ & $128,0 \pm 2,1$ & $\begin{array}{c}152,2 \pm 1,6 \\
\Delta+18,9\end{array}$ & $132,2 \pm 2,1$ & $\begin{array}{c}143,7 \pm 1,28^{* *} \\
\Delta+8,70\end{array}$ \\
\hline $\mathrm{DBP}, \mathrm{mm} \mathrm{Hg}$ & $77,4 \pm 2,3$ & $\begin{array}{l}86,0 \pm 1,9 \\
\Delta+11,11\end{array}$ & $74,4 \pm 1,8$ & $\begin{array}{c}80,6 \pm 1,8 \\
\Delta+8,33\end{array}$ \\
\hline Heart rate, min. & $75,2 \pm 2,9$ & $\begin{array}{l}87,3 \pm 2,6 \\
\Delta+16,09\end{array}$ & $74,6 \pm 2,1$ & $\begin{array}{c}79,4 \pm 1,3 * * \\
\Delta+6,43\end{array}$ \\
\hline Feeling, score & $1,4 \pm 0,07$ & $\begin{array}{c}2,78 \pm 0,09 \\
\Delta+98,57\end{array}$ & $1,36 \pm 0,08$ & $\begin{array}{c}2,32 \pm 0,08^{* *} \\
\Delta+70,59\end{array}$ \\
\hline Dyspnea, score & $1,08 \pm 0,09$ & $\begin{array}{c}1,32 \pm 0,06 \\
\Delta+22,22\end{array}$ & $1,06 \pm 0,07$ & $\begin{array}{c}1,15 \pm 0,04 \\
\Delta+8,49\end{array}$ \\
\hline $\begin{array}{l}\text { Angina pectoris, } \\
\text { score }\end{array}$ & $0,99 \pm 0,06$ & $\begin{array}{c}1,192 \pm 0,03 \\
\Delta+20,40\end{array}$ & $0,94 \pm 0,05$ & $\begin{array}{c}1,03 \pm 0,04 * * \\
\Delta+9,57\end{array}$ \\
\hline Traveled distance, $\mathrm{m}$ & \multicolumn{2}{|c|}{$384,2 \pm 12,8$} & \multicolumn{2}{|c|}{$\begin{array}{l}420,1 \pm 11,1^{*} \\
\Delta+9,34\end{array}$} \\
\hline
\end{tabular}

Notes: 1. Significance of difference of indicators in comparison with values before intervention: $*<0,05$; $* *<0,01.2 . \Delta-$ the percentage of increase $(+) /$ decrease $(-)$ compared to the values before treatment.

In the course of complex rehabilitation, the patient receives information about the dynamics of recovery through exercise, thus forming an idea of the capabilities of the body in the present and the perspectives of recovery. The progress of the human body in the course of rehabilitation forms an understanding of the optimum of physical abilities that can be achieved after the treatment and rehabilitation. In general, the optimization of the sensitive component of IPH is ensured. 
Optimization of the value-motivational component of IPH is realized as enhancing motivation for physical activity and leading a healthy lifestyle and developing responsibility for one's health. Psychological support of this component will provide an improvement in understanding of one's own system of life values and value of health, will provide an expansion of life prospects, finding new life goals, in particular by increasing physical activity.

Optimization of the cognitive component of IPH consists in understanding the complexity of the disease, the role of various factors in its development, and is ensured through the cooperation of members of a multidisciplinary team. The physical component of rehabilitation in the cognitive component of $\mathrm{HCV}$ is manifested as self-knowledge through movement, awareness and comprehension of the vital decisions that are associated with the new way of life. After rehabilitation, we note the development of the ability to identify the successful strategies for improving the physical condition of the body, expanding the scope of knowledge about the content and effectiveness of physical activity.

Regular physical activity by the "Program" helps to build confidence and to optimize the emotional response to their condition during their execution. Psychological support of the physical component of rehabilitation provides the development of awareness of positive emotions from movement. In general, we note a decrease in the level of anxiety, improvement of the patient's wellbeing, which testifies to the optimization of the emotional component of IPH.

Particularly valuable is the qualitative change in the behavioral component of IPH, rehabilitation stimulates specific human actions, driven by the system of their knowledge and decisions, and aimed at achieving subjectively meaningful goals for health recovery.

Conclusions. The physical component in complex multidisciplinary rehabilitation of cardiac patients with acute coronary syndrome (ACS) is necessary and provides the optimum possible recovery of the body, promotes adherence to treatment, provides awareness of the role of various disease development factors. In the course of physical rehabilitation, the patient chooses new strategies for recovery and preservation of health.

The physical component of rehabilitation provides a positive change in the patient's objective and subjective health indicators.

\section{REFERENCES}

1. Уніфікований клінічний протокол екстреної, первинної, вторинної, третинної медичної допомоги та медичної реабілітації «Гострий коронарний синдром без елевації сегмента ST», наказ МОЗ України 03.03.2016 №164

2. Neumann F-J, Sousa-Uva M, Ahlsson A, Alfonso F, Banning AP, Benedetto U, et al. 2018 ESC/EACTS Guidelines on myocardial revascularization. European Heart Journal [Internet]. 2018 Aug [cited 2018 Aug 25]; 00:1-96. Available from: https://academic.oup.com/eurheartj/advancearticle/doi/10.1093/eurheartj/ehy394/5079120 doi:10.1093/eurheartj/ehy394e0152367. Available from: https://www.ncbi.nlm.nih.gov/pmc/articles/PMC4830576/

3. Leon AS, Franklin BA, Costa F. et al. Cardiac rehabilitation and secondary prevention of coronary heart disease: an American Heart Association scientific statement from the Council on Clinical Cardiology (Subcommittee on Exercise, Cardiac Rehabilitation, and Prevention) and the Council on Nutrition, Physical Activity, and Metabolism (Subcommittee on Physical Activity), in collaboration with the American association of Cardiovascular and Pulmonary Rehabilitation. Circulation. 2005; 111:369-376

4. Vakaliuk IP. Nesterak RV. Hasiuk MB. Program of psychological rehabilitation of cardiac patients by optimization of the internal picture of health. Author’s Certificate № 75681 dated 29.12.2017

5. Малиновская ИЭ, Шумаков ВА, Терещенко НМ. Физическая реабилитация в комплексной программе лечения больных, перенесших инфаркт миокарда. Український кардіологічний журнал . 2015;6: 90-99.

6. Гайгер Г. Применение шкалы индивидуального восприятия физической нагрузки в реабилитации и спортивной медицине. лечебная физкультура и спортивная медицина.2010;3(75):24-27.

7. Лизогуб ВГ, Савченко ОВ, Запека ЮС, Байцер МС. Застосування 6-хвилинного тесту з ходьбою в кардіології. Первый независимый научный вестник. 2015; 4:12-16.

8. La Rovere MT, Pinna GDЮ Olmetti $F$ et al. The 6-minute walking test and all-cause mortality in patients undergoing a post cardiac surgery rehabilitation program. European journal of preventive cardiology. 2015;22(1):20-26.

9. Nesterak RV, Gasyuk MB. Pilot investigation of the method of interactive training of patients at the stage of medical rehabilitation and treatment Deutscher Wissenschaftsherold, German Science Herald. 2017; 4: 38-41. DOI:10.19221/2017412.

10. Hasiuk MB, Nesterak RV. Internal picture of health of patients who had ischemic heart disease and myocardial infarction: an empirical study. Naukovyy visnyk Khersonskoho derzh. universytetu. 2018; 2 (2): 149-155.

11. Нестерак РВ, Гасюк МБ. Ефективність медико-психологічної реабілітації у хворих з гострим коронарним синдромом. Психосоматична медицина та загальна практика. 2019;1(4):1-7.

12. Bondar VP, Borysova IS, Nechuy-Viter LP. Optimization of rehabilitation of persons with a cardiac profile disability: the place of the psychologist. Visnyk VDNZU "Ukrayinska medychna stomatolohichna akademiya". 2018; 18 (61): 14-17.

13. Швед МІ, Левицька ЛВ, Липовецька СЙ. Базові принципи кардіоребілітації пацієнтів після інфаркту міокарда. Кардіореабілітація. 2018.3(7):49-53. 